\title{
ORNAMEN MASJID ASASI SIGANDO KOTA PADANGPANJANG
}

\author{
Mirda Aryadi ${ }^{1 *}$, Asril $\mathbf{S}^{2 *}$, Febri Yulika ${ }^{3 *}$ \\ Pengkajian Seni Kriya Program Pascasarjana \\ Institut Seni Indonesia Padangpanjang \\ Jl. Bahder Johan, Guguak Malintang, Padangpanjang, Kota Padangpanjang, 27126. \\ Sumatera Barat. Indonesia \\ Email:amier.aryadhi@gmail.com
}

\begin{abstract}
Abstrak
Masjid Asasi Sigando menerapkan ornamen sebagai salah satu bagian dari bangunannya. Fungsi secara umum dari penempatan ornamen pada masjid Asasi sebagai penghias, hal ini juga berlaku pada bangunan yang khas Minangkabau lainnya. Penempatan ornamen pada masjid ini, hampir terdapat pada seluruh dinding luar. Ornamen yang diterapkan pada bagian dinding masjid seperti singok, pereang, papan banyak, papan sakapieng, dan salangko. Penelitian ini menggunakan metode penelitian kualitatif yang berifat deskriptif. Ornamen Masjid Asasi memiliki keindahan dari segi motif yang belum dikaji secara keilmuan. Pengumpulan data dilakukan dengan cara obervasi, wawancara, dokumentasi dan studi pustaka. Hasil tentang ornamen Masjid Asasi bahwa ide penciptaan motif ornamen berlandaskan pada bentuk alam seperti, tumbuhan, hewan, alam benda dan manusia. Selain itu penempatan masing-masing motif juga disusun pada bagian masjid yang memiliki nama tertentu.
\end{abstract}

Kata Kunci: masjid asasi, ornamen, motif.

\begin{abstract}
Asasi Sigando Mosque uses ornaments as one part of the building. The general function of the placement of ornaments on the Asasi mosque as decoration, this also applies to other typical Minangkabau buildings. Placement of ornaments on this mosque, almost found on the entire outer wall. Ornaments applied to the walls of the mosque such as singok, pereang, papan banyak, papan sakapieng, and salangko. This research uses descriptive qualitative research methods. Asasi Mosque ornaments have beauty in terms of motifs that have not been studied scientifically. Data collection is carried out by means of observation, interviews, documentation and literature study. The result of Asasi Mosque ornaments is that the idea of creating ornamental motifs is based on natural forms such as plants, animals, natural objects and humans. In addition, the placement of each motif is also arranged on the part of the mosque that has a certain name.
\end{abstract}

Keywords: asasi mosque, ornaments, motifs.

\section{PENDAHULUAN}

Masjid Asasi Sigando, yang merupakan salah satu wisata religi dan menjadi daya tarik pariwisata di Sumatera Barat. Daya tarik dari masjid ini karena sejarah dan ornamen yang terukir di dinding masjid. Masjid Asasi Sigando saat ini masih digunakan untuk kegiatan ibadah umat Islam. Masjid Asasi memiliki bentuk bangunan segi empat, melambangkan bahwa yang mencetuskan pembangunan masjid adalah Nagari Ampek Jurai.

SP. Gustami, (2008:4), menerangkan ornamen berupa komponen produk seni yang ditambahkan atau sengaja dibuat untuk tujuan hiasan. Di samping tugasnya menghiasi yang implisit menyangkut segi-segi keindahan, misalnya untuk menambah indahnya suatu barang sehingga lebih bagus dan menarik, akibatnya mempengaruhi pula dari segi penghargaannya, baik dari segi spiritual maupun material/ finansialnya).

Ornamen pada masjid Asasi Sigando berfungsi sebagai penghias masjid. Motif Masjid Asasi Sigando terdiri dari tiga jenis utama berupa motif tumbuhan, motif hewan dan motif benda sehari-hari. Motif yang diterapkan pada masjid Asasi Sigando pada dasar penciptaannya telah mengalami stilisasi. Dharsono (2017:39) menjelaskan Stilisasi merupakan cara penggambaran bentuk untuk mencapai bentuk keindahan dengan cara menggayakan objek atau benda yang digambar, yaitu dengan cara menggayakan setiap kontur pada objek benda tersebut. Sumber objek ide yang diterapkan pada ukiran masjid Asasi Sigando bertemakan kehidupan alam. Tema dari kehidupan alam ini sesuai dengan pepatah Minangkabau Alam Takambang Jadi Guru. 


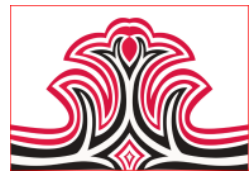

Motif-motif yang ada pada dinding masjid Asasi Sigando memiliki nama pada setiap bagiannya seperti: singok, pereang, papan banyak, papan sakapieng, dan salangko. Penempatan dari motif ornamen disesuaikan dengan kaidah yang diatur dalam masyarakat terkait makna dari masing-masing motif. Bertolak pada uraian diatas rumusan masalah dari penelitian ini adalah: 1). Apa jenis dan nama motif yang ada pada ornament masjid Asasi? 2). Bagaimana dinding apa saja yang menerapkan motif ornament pada masjid Asasi?. Adapun tujuan dari penelitian ini untuk mengetahui: 1). Mengenai jenis dan nama motif yang digunakan dalam ornament masjid Asasi, 2). Mengetahui bagian dinding masjid Asasi yang memiliki penerapan motif ornamen.

\section{KAJIAN TEORI}

Nama motif yang ada di Minangkabau diambil dengan bentuk dasar yang digubah. Motif itu terdiri dari nama-nama tumbuhan, binatang, ataupun benda lainnya (Risman Marah, 1987:14). Motif yang ada pada masjid Asasi juga menerapkan keberagaman nama motif seperti yang ada pada bangunan adat Minangjabau pada umumnya.

\section{METODE PENELITIAN}

Penelitian ini menggunakan metode deskriptif analisis dengan pendekatan kualitatif. Penelitian kualitatif adalah metode penelitian yang digunakan untuk meneliti pada kondisi objek yang alamiah. Penelitian ini diperlukan untuk melihat bagaimana ornamen yang terdapat pada Majid Asasi Sigando dikaji secara motif yang sesuai dengan kaidah yang terdapat pada jenis Motif Minangkabau. Terkait dengan penelitian terebut yang didahului oleh tinjauan putaka, obervasi dan wawancara.

\section{HASIL DAN PEMBAHASAN}

\section{Hasil}

\section{1). Struktur Masjid}

Bentuk fisik masjid yang ada di Minangkabau juga dipengaruhi oleh kelarasan yang ada di Minangkabau dari segi bangunannya, yakni rumah gadang maupun balairung. Bentuk fisik masjid kelarasan bodi chaniago dan koto piliang, memiliki bentuk yang tampak berbeda terlihat dari atap gonjongnya. Masjid kelarasan bodi chaniago hanya memiliki satu gonjong, sedangkan kelarasan koto piliang atap puncaknya memiliki empat buah singok beserta gonjongnya. sedangkan persamaan dari bangunan masjid ini terletak pada bentuknya yang peregi empat, lantainya yang rata. Selain dari lantainya yang rata, hal ini memiliki makna bahwa setiap manusia memiliki
Gorga : Jurnal Seni Rupa

Volume 09 Nomor 01 Januari-Juni 2020

p-ISSN: 2301-5942 | e-ISSN: 2580-2380

kedudukan yang sama dimata Allah (Wawancara dengan Nuzirwan, April: 2016).

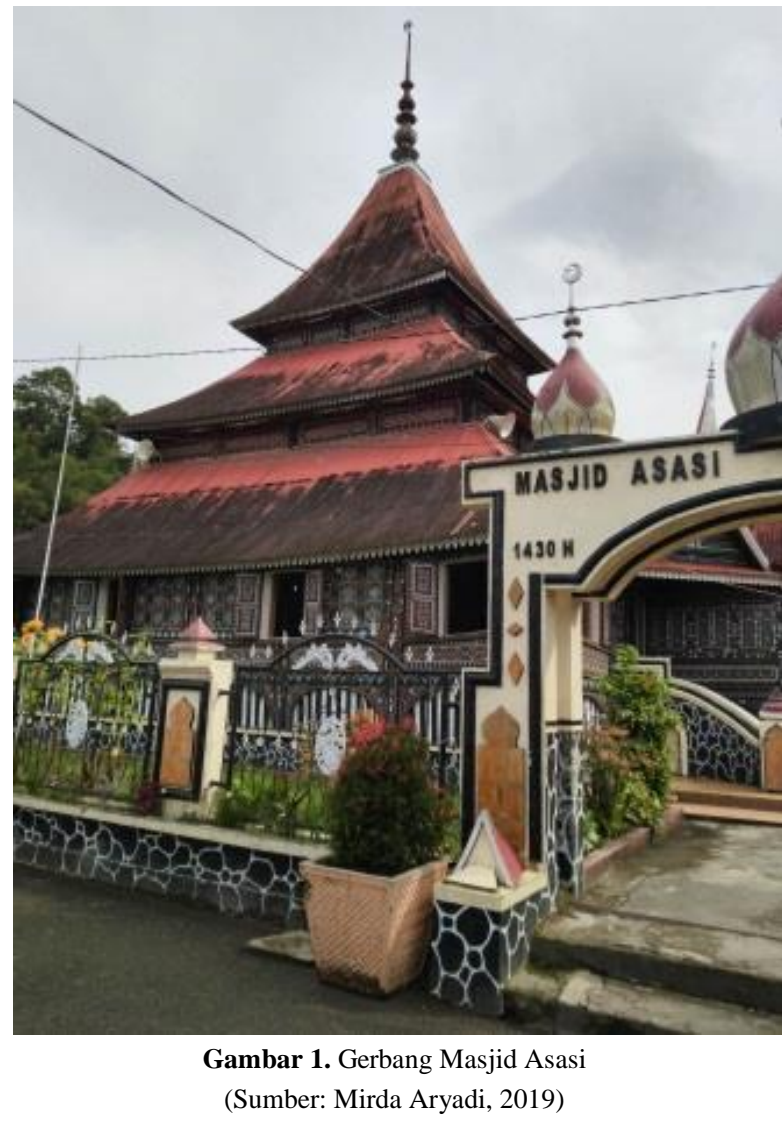

Bentuk Masjid Asasi Sigando menganut kelarasan bodi chaniago, dimana pada bagian serambi dan mihrabnya memiliki singok, yang jumlahnya meliputi pada serambi depan tiga buah singok dan pada mihrabnya satu. Perbedaan pada bagian ingok ini menandakan bahwa agama yang dilambangkan dengan bagian utama masjid, serambi serta mihrab yang beratap singok merupakan perwujudan dari "adat basandi syarak syarak basandi kitabullah". Falsafah tersebut memiliki makna bahwa adat dan agama dapat sejalan dalam kehidupan masyarakat. Penerapannya dalam kehidupan juga dapat ditemui dengan lekatnya unsur agama dalam setiap kegiataan adat. 

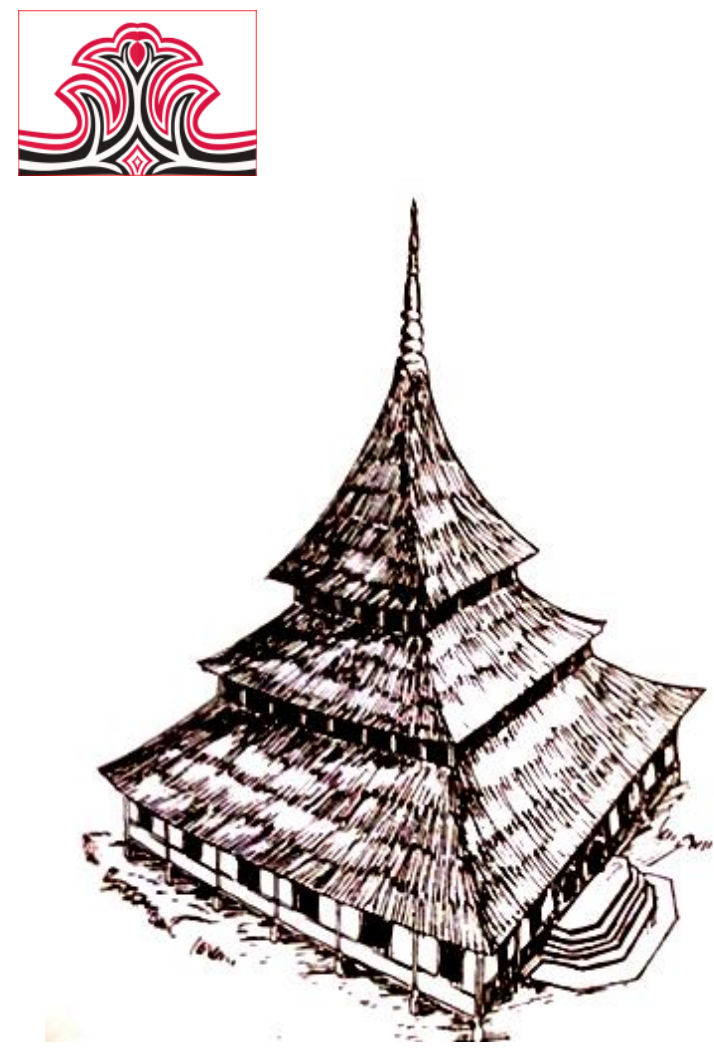

Gambar 2. Bentuk Masjid dan Surau Keselarasan Bodi Caniago (Sumber: A.A. Navis, 1987: 140, Repro oleh Mirda Aryadi, 2019)

Ornament yang ada pada Masjid Asasi Sigando memiliki pola yang tertata pada dinding bangunannya. Penempatan bidang ornamen dan penerapan motif memiliki pola yang berulang dan teratur. Pola yang teratur ini dapat ditemui disetiap sisi bangunan masjid. Pola penerapan ornament ini diletakkan pada setiap bagian masjid, yang setiap bagian masjid memiliki nama dalam bagian struktur bangunannya. Berikut adalah bagian dari setiap bangunan masjid.

\section{(1). Pereang}

Pereang merupakan bagian dari singok yang letaknya sebagai penutup pada bagian bawah bidang singok. Pereang yang ada di Masjid Asasi sebagian besar letaknya berada di bawah singok, namun juga terdapat pada bagian tingkat atas dan sekelilingnya. Bentuk pereang ini memanjang dan letaknya tidak tegak, dan memiliki kemiringan yang mengarah ke dalam dari bangunan.

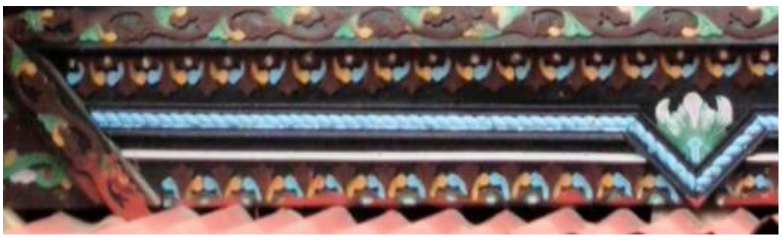

Gambar 3. Pereang Singok Pindu Depan (Sumber: Mirda Aryadi, 2019)
Gorga : Jurnal Seni Rupa

Volume 09 Nomor 01 Januari-Juni 2020

p-ISSN: 2301-5942 | e-ISSN: 2580-2380

\section{(2). Papan Sakapieng/Panin Bandua}

Papan sakapiang dapat diartikan sebagai kekuatan, kekompakan dan kesatuan. Papan sakapieng merupakan salah satu bagian untuk menutup kontruksi masjid. Bentuk papan ini persegi panjang, letaknya antara papan banyak dan salangko. Penerapan papan sakapieng meliputi sekeliling bangunan, dan tiap lembar dibatasi dengan redeang sudut.

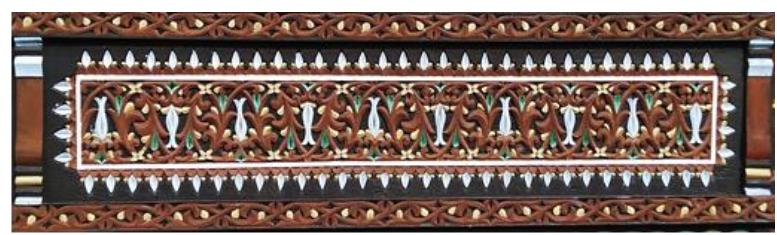

Gambar 4. Papan Sakapiang pada Serambi Depan (Sumber: Mirda Aryadi, 2019)

\section{(3). Singok}

Singok merupakan bagian atap yang berbentuk segitiga. Pada Masjid Asasi Sigando memiliki empat singok, penempatan serta ukuran yang dimilikinya berbeda-beda. Singok pada bagian serambi depan dan mihrab memiliki ukuran yang besar. Singok pada bagian lain memiliki ukuran yang kecil, dan terletak pada pintu depan sebelah kiri dan kanan.

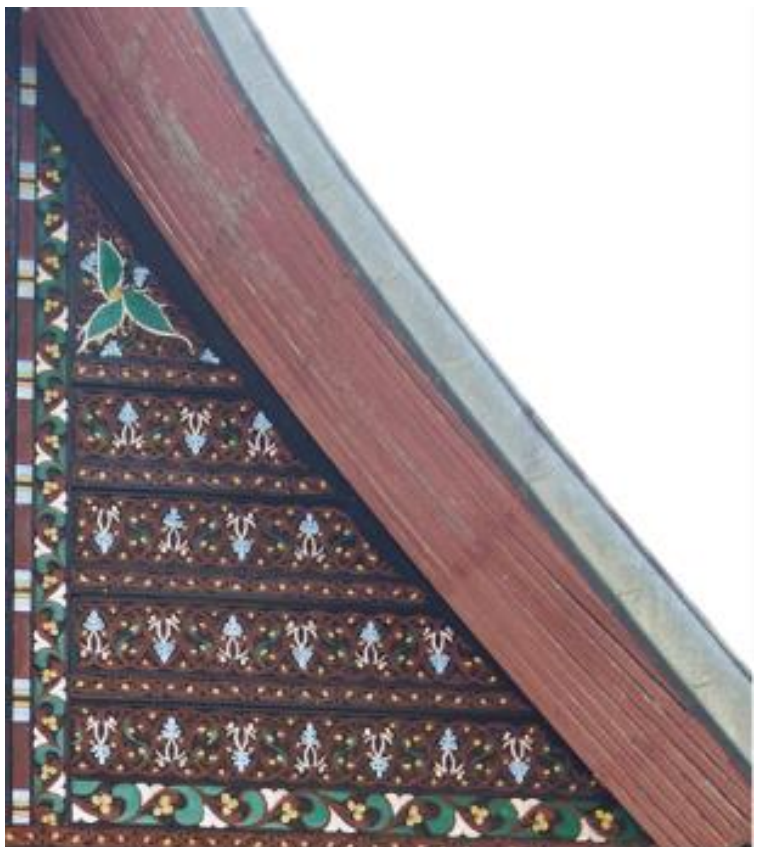

Gambar 5. Singok pada mihrab dan Serambi Depan (Sumber: Mirda Aryadi, 2019)

\section{(4). Pintu dan Jendela}

Masjid Asasi Sigando terdapat dua pintu masuk pada bagian depannya. Pintu masuk masjid terletak antara bagian kiri dan kanan dari bagian serambi masjid. Jendela pada masjid berjumlah 12 pasang. Pintu dan jendela masjid tidak luput dari penerapan ornamen 


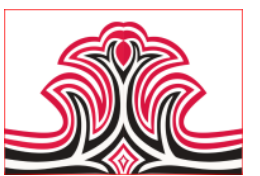

sebagai penghiasnya. Penerapan ornament motif yang ada pada pintu dan jendela berbeda satu dengan yang lainnya, motif yang digunakan pada pintu yaitu Pakiah Sailan sedangkan pada jendela motif yang digunakan kuciang lalok. Motif Pakiah Sailan tidak ditemukan pada referensi manapun karena motif ini merupakan nama dari orang yang merenovasi masjid Asasi pada tahun 1970-an (Nuzirwan, Wawancara 2016, Sigando).

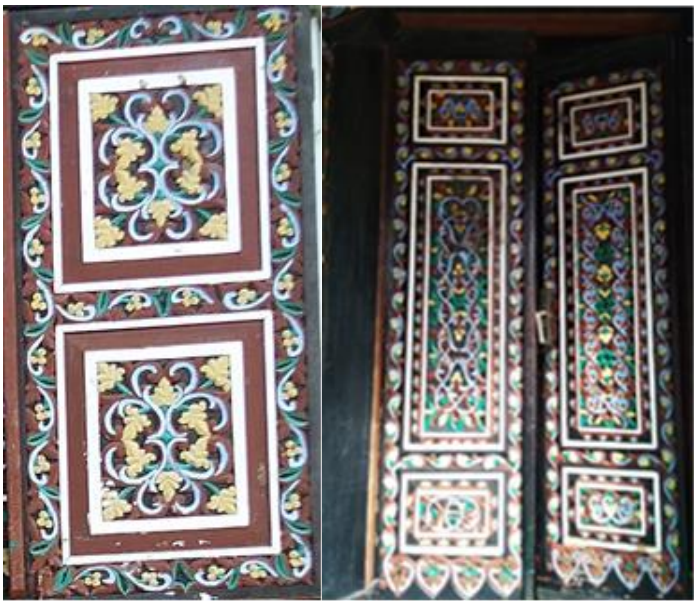

Gambar 6. Penerapan Motif Pakiah Sailan pada Jendela dan Pintu (Sumber: Mirda Aryadi, 2019)

\section{(5). Papan Banyak}

Papan banyak merupakan bagian bidang yang melapisi sebagian besar dinding masjid, hal ini karena ukuran papan banyak lebih lebar dibandingkan bidang yang lain. Papan banyak dikelompokkan beberapa bagian berdasarkan penempatannya, yaitu pada: papan banyak dinding tapi dan papan banyak dindiang ari. Bagian dinding yang menghadap kedepan disebut dindiang tapi, dan bagian dinding yang menghadap kesamping disebut dindiang ari.
Gorga : Jurnal Seni Rupa

Volume 09 Nomor 01 Januari-Juni 2020

p-ISSN: 2301-5942 | e-ISSN: 2580-2380

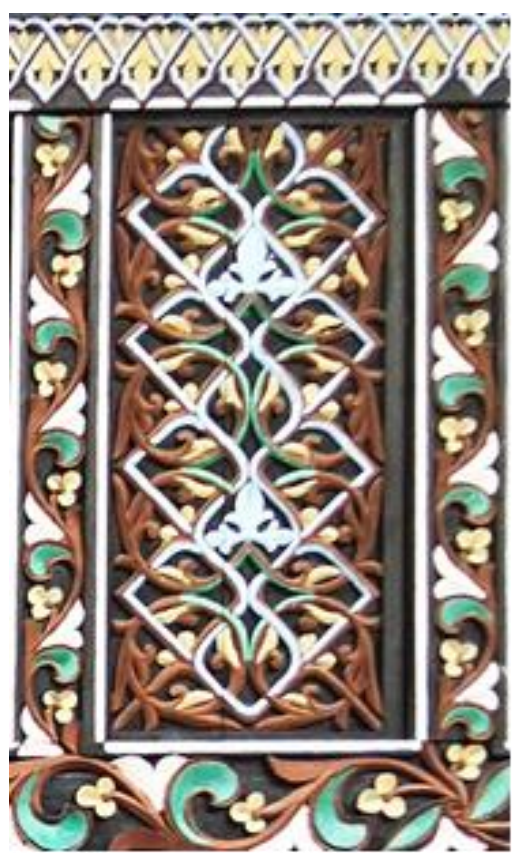

Gambar 7. Papan Banyak Serambi Depan dan Dinding Mihrab (Sumber: Mirda Aryadi, 2019)

\section{(6). Redeang Suduik}

Redeang suduik adalah bagian dari pembatas sudut masjid, redeang suduik ditemukan pada bagian dinding tengah. Redeang suduik dapat ditemukan pada semua sisi masjid, dan pada bagian bawahnya terdapat berupa pasak yang juga terdapat ukiran motif. Pasak yang ada pada bagian redeang suduik merupakan bagian dari konstruksi masjid, yang berfungsi menyambung bagian dari dalam ruangan. Motif yang terdapat pada pasak ini adalah kaluak paku.

\section{(7). Salangko}

Salangko merupakan bagian dari masjid yang letaknya pada bawah setelah papan sakapieng. Fungsi dari salangko ini sebagai penutup tiang bagian bawah masjid. Pada bagian kolong ini juga memiliki nama yaitu kalalawa, dahulunya berbahan bambu sebagai penutupnya. Pada masa sekarang berbahan kayu dan ada yang disemen. Fungsi yang menarik dari kolong ini sebagai tempat alat ladang, dan hewan ternak seperti itik maupun ayam. Namun fungsi itu hanya berlaku pada rumah gadang, bukan pada surau gadang. Salangko dikiaskan sebagai bagian dari pakai penghulu, yaitu kain samping.

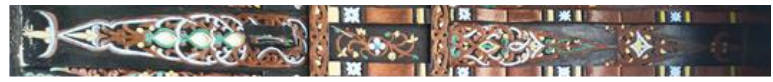

Gambar 8. Redeang Suduik pada Seluruh Dinding Masjid dan Singok

(Sumber: Mirda Aryadi, 2019) 


\section{2). Jenis Motif pada Ornamen Masjid}

Analisis awal ukiran yang adapada masjid AsasiSigando memilikidasardari motif ukiran yang sama pada Rumah Gadang seperti yang dikemukakan oleh Martamin (1976:3) : "Jenis ukiran pada bangunan dan benda-benda itu hampir sama saja dan semuanya berindukkan pada jenis ukiran yang terdapat pada Rumah Gadang”.

Ukiran tidak saja mengungkapkan keindahan semata, tetapi juga mengandung pesan-pesan pendidikan yang tersirat didalamnya."Setiap motif ragam hias yang dipahatkan pada rumah adat mengandung makna yang dalam, membawa pesan-pesan yang disamarkan kedalam motif-motif yang indah" (RismanMarah, 1987:9).

Selain nilai sejarahnya yang tinggi, keistimewaan bangunan Masjid Asasi Sigando tidak terlepas dari salah satu unsur bangunannya, yaitu ornamen yang terdapat pada masjid. Ornamen yang ada memiliki motif yang beragam terdiri dari jenis tumbuhan hewan dan alam benda dan manusia. Bentuk motif ini telah mengalami stilisasi, sehingga bentuknya berbeda dari objek aslinya.

Berikut tabel dari jenis dan nama motif yang terdapat pada majid asasi sigando.

Tabel 1. Jenis-Jenis Motif

\begin{tabular}{|c|c|c|c|}
\hline No & $\begin{array}{c}\text { Motif Alam } \\
\text { Benda Dan } \\
\text { Manusia }\end{array}$ & $\begin{array}{c}\text { Motif } \\
\text { Tumbuhan }\end{array}$ & Motif Hewan \\
\hline 1 & ati-ati & kaluak paku & $\begin{array}{l}\text { itiak pulang } \\
\text { patang }\end{array}$ \\
\hline 2 & batirai & pucuak rabuang & $\begin{array}{l}\text { itiak pulang } \\
\text { patang }\end{array}$ \\
\hline 3 & kipeh cino & $\begin{array}{l}\text { sakek } \\
\text { tagantuang }\end{array}$ & $\begin{array}{l}\text { kuciang } \\
\text { bagaluik }\end{array}$ \\
\hline 4 & $\begin{array}{l}\text { langik basintak } \\
\text { naiak buoni } \\
\text { basintak turun }\end{array}$ & $\begin{array}{l}\text { bungo palo } \\
\text { patah }\end{array}$ & $\begin{array}{l}\text { labah } \\
\text { mangirok }\end{array}$ \\
\hline 5 & $\begin{array}{l}\text { lapiah ampek jo } \\
\text { bungo kunyik }\end{array}$ & siku bungo lado & ramo-ramo \\
\hline 6 & lapiah duo & bungo & sapik kalo \\
\hline 7 & lapiah tigo & $\begin{array}{l}\text { baji jo pucuak } \\
\text { rabuang }\end{array}$ & \\
\hline 8 & pakiah sailan & daun bodi & \\
\hline 9 & pilin ampek & bungo & \\
\hline 10 & pitih-pitih & & \\
\hline 11 & saik kalamai & & \\
\hline 12 & salimpat & & \\
\hline 13 & saluak laka & & \\
\hline 14 & $\begin{array}{l}\text { sikambang } \\
\text { manih }\end{array}$ & & \\
\hline 15 & tirai babungo & & \\
\hline 16 & $\begin{array}{l}\text { tirai timba } \\
\text { baliak }\end{array}$ & & \\
\hline 17 & Limpapeh & & \\
\hline 18 & Taji Siarek & & \\
\hline 19 & $\begin{array}{l}\text { Tivai Bungo } \\
\text { Intan }\end{array}$ & & \\
\hline
\end{tabular}

Gorga : Jurnal Seni Rupa

Volume 09 Nomor 01 Januari-Juni 2020

p-ISSN: 2301-5942 | e-ISSN: 2580-2380

\section{Pembahasan}

Bagian dari masjid Asasi sigando seperti singok, pereang, papan banyak, papan sakapieng, dan salangko. Merupakan gambaran dari bentuk bangunan yang ada pada Rumah Gadang. Pembeda dari bangunan masjid Asasi Sigando dengan Rumah Gadang hanya terletak pada atapnya. Bentuk atap masjid memiliki satu gonjong, sedangkan pada Rumah Gadang terkadang 5 sampai 7 gonjong.

Selain itu pada jenis keragaman motif ornamen pada masjid Sigando memiliki jenis yang sama dengan motif yang ada di Minangkabau pada umumnya. Motif yang terdapat pada masjid Asasi Sigando, keunikannya pada jumlah pengulangan motif yang banyak dan meliputi hampir seluruh bangunan luar. Masjid lain yang sejenis dengan bentuk Masjid Asasi penerapan motif hanya alakadar saja.

\section{KESIMPULA DAN SARAN}

\section{Kesimpulan}

Berdasarkan penelitian yang dilakukan Masjid Asasi Sigando Nagari Gunung nerupakan bangunan peninggalan sejarah yang keberadaannya telah ada sekitar abad 17. Keberadaan masjid asasi saat ini dilestarikan oleh masyarakat sekitar dan instansi terkait yang ada di Padangpanjang, dan juga merupakan pemersatu nagari yang ada disekitarnya.

Bentuk Masjid Asasi Sigando menganut kelarasan Bodi Caniago di mana pemerintahannya berlandaskan pada musyawarah dan mufakat, sehingga tercermin dari bentuk masjidnya yang persegi dan gonjong yang satu memuncak keatas. Ornament masjid dipengaruhi oleh konsep alam dalam penerapan motifnya, hal ini juga berlandaskan pada falsafah orang Minang "alam takambang jadi guru". Berdasarkan hal itu penerapan motif terdiri dari motif tumbuhan, hewan, alam benda dan manusia.Penempatan motif minangkabau pada masjid asasi terdiri dari beberapa struktur bangunan masjid seperti: singok, pereang, redeang suduik, papan banyak, papan sakapiang, dan salangko.

\section{Saran}

Bekaitan dengan penelitian ini, diharapkan bagi pemerintah dan masyarakat dapat menjaga peninggalan masa lalu agar nilai keindahan dan falsafah dapat diturunkan dan diajarkan untuk generasi selanjutnya. Dan semoga dapat memberikan sumbangan terhadap ilmu pengetahuan, dan menjadi rujukan untuk peneliti berikutnya. 


\section{DAFTAR RUJUKAN}

Gustami, SP. (2008). Nukilan Seni Ornamen Indonesia. Yogyakarta: ISI Yogyakarta.

Marah, Risman. (1987). Ragam Hias Minangkabau. Yogyakarta: Dirjen Kebudayaan Departemen Pendidikan Dan Kebudayaan.

Martamin, Mardjani. (1978). Ukiran Rumah Adat Minangkabau dan artinya. Padang: FKPS IKIP Padang.

Sony Kartika, Dharsono. (2017). Seni Rupa Modern. Bandung: Rekayasa Sains. 